$A D D I N$, Volume 12, Number 1, February 2018

\title{
VALUES BASED SUPERIOR STUDENTS' LEARNING BEHAVIOUR
}

\author{
Nadhirin \\ IAIN Kudus, Central Java, Indonesia \\ nadhirin072@gmail.com
}

\section{Abstract}

The purposes of this research were to find (1) organizational learning behavior of superior students (2) the source of values that underlies the superior students' learning attitude and behavior (3) superior students' learning behavior in school and (4) learning interaction between teacher and superior students at school. This research used qualitative approach and pospositivistic paradigm. The research data was collected by interview, observation and documentation. Technique of data validity test used technique, source and time triangulation. Data were analyzed by Miles Hubermans interactive cycling techniques: collecting, reducting, displaying and verifying. The subjects of this research were the leaders, educators, students and stakelholders of MANU Banat, Kudus, Central Java, Indonesia. The results of this study are (1) Students whose good achievement in the academic and non academic field are students who study in school organization unit with progressive commitment and spirit. A good and conducive organizational culture that is maintained by all members of the organization is very supportive to the superior and competitive students' achievement (2) The sources of values or viewpoint that make the students become outstanding achievers is the accumulation of values formed from the religious and dicipline family environment, consistent 
school environment with the practice of religion that inculcates values of virtue, dicipline in learning, honesty, competitiveness and norms prevailing in society (3) high school students' behavioral typology and learning attitudes are responsive stimuli. The more rules and structured tasks created by the school and subject teachers, the students' attitudes and motivation will be more intense and vice versa (4) students whose outstanding achievement have a close relationship with the teacher. Teachers for them are as parents, mentors, friends to communicate and belp their non-academic problems.

Keywords: Learning Behavior, Superior Students, Value Based.

\section{Abstrak}

PERILAKU BELAJAR SISWA UNGGUL BERBASIS NILAI. Tujuan penelitian ini untuk mengetabui (1) perilaku organisasi tempat siswa sekolah unggul belajar (2) sumber nilai (values) yang melandasi sikap dan perilaku belajar siswa unggul (3) perilaku belajar siswa unggul di sekolah dan (4) interaksi belajar antara guru dengan siswa unggul di sekolah. Penelitian ini menggunakan pendekatan kualitatif, paradigma pospositivistik. Data penelitian dikumpulkan dengan wawancara, observasi dan dokumentasi. Teknik uji keabsahan data menggunakan triangulasi, meliputi triangulasi teknik, sumber dan waktu. Data dianalisis dengan teknik siklus interaktif Miles Hubermans, dengan siklus collecting, reducting, displaying dan verifying. Subyek penelitian ini adalah pimpinan madrasah, tenaga pengajar, siswa dan stakeholders $M A$ NU Banat, Kudus, Jawa Tengah, Indonesia. Hasil dari penelitian ini adalah (1) Siswa yang memilike pretasi baik di bidang akademik. maupun non akademik adalah siswa yang belajar di satuan organisasi sekolah yang memiliki komitmen dan semangat untuk. maju. Budaya organisasi yang baik dan kondusif yang dipelibara oleh selurub anggota organisasi sangat mendukung terhadap capaian prestasi siswa yang unggul dan kompetitif (2) Sumber nilai atau pandangan hidup yang membuat siswa menjadi berprestasi unggul adalah akumulasi nilai (values) yang terbentuk dari lingkungan keluarga yang religius 
dan disiplin, lingkungan sekolah yang konsisten dengan pengamalan agama dalam lingkungan sekolah yang menanamkan nilai-nilai tentang keutamaan akblak, disiplin dalam belajar, jujur, kompetitif dan mengindabkan norma yang berlaku di masyarakat. (3) tipologi perilaku dan sikap belajar siswa setingkat sekolah menengah atas adalah stimulus responsif. Semakin banyak peraturan dan tugas-tugas terstruktur yang dibuat oleh sekolah dan guru mata pelajaran, maka sikap dan motivasi belajar siswa akan lebih intens dan sebaliknya (4) siswa yang berprestasi unggul memiliki kecenderungan bubungan yang dekat dengan guru. Bagi siswa yang unggul, guru sebagai orang tua, pembimbing, teman dalam komunikasi dan guru membantu masalah-masalah siswa yang bersifat non akademis.

Kata Kunci: Perilaku Belajar, Siswa Unggul, Basis Nilai.

\section{A. Introduction}

Education in achieving goals involves many components. The education components are all resources that are used as inputs to be managed professionally in achieving maximum educational goals. One of input in education management is the value system adopted by an organization. The values system adopted by a community, including the education community, greatly determines the education direction and achievements. Values are principles and meaningful views that underlie an action.

Good education management without good values organization support will not achieve maximum results. Most educational institutions or organizations are less able to develop and preserve a value system adopted or used as a view of life for the entire school community. This value system is hidden or not explicitly visible on the surface that serves as a spirit and direction for students, teachers and school community in carrying out their respective duties and obligations. The graduates with perfect personality and 
achievement have academic abilities, physical and spiritual health, and understand the social life culture. This complete personality and achievement is what researchers call as superior students.

When education is viewed from the smallest and main activity unit, it is the learning process. The learning process includes teachers, students, evaluation materials and techniques, learning media, teaching methods and strategies, and learning spaces. Students are the main component other than the teacher in the learning process. Teaching strategies are very diverse and have different theoretical foundation. This learning strategies difference is caused by various assumptions about human psychological perspectives that are very unique and complex. Effective teaching strategies in one place are not necessarily effective in other places. Whatever teaching strategy in learning activities will be ineffective if it does not consider the students' learning behavior and characteristics.

Students who gather in a learning activity cannot really be seen as a simple community. Class is actually the same community as the community in general. A collection of students in a learning space is called a learning community. Like the general community, the students carry out the learning process in the classroom, The students' learning community has different principles, views and value systems. Therefore, an intelligent teacher is a teacher who knows the theory and teaching strategy. And the teacher must also learn and understand the students' learning behavior. By doing those points, the teacher will truly function well as one of the sources of student information, as well as role models, substitute for parents and at the same time as a good partner in learning. 
The facts show that not many teachers are able to put and function as what have described above. In practice, the teacher places and functions more as the knowledge printing machine and the value system doctrines for students. This viewpoint sees the class as a production space for creating students' knowledge that is mechanical or even boring. Such learning spaces will be very similar to cloning knowledge. If it is maintained and preserved, it will greatly disrupt the humanist educational objectives. The learning process requires a standard instrument and applies equally to a learning process and in the evaluation process, but it must be kept in mind that different students' character and learning behavior cannot necessarily be viewed and addressed equally.

Other facts can be seen from many non-formal institutions, such as skills courses, private courses, tutoring and special guidance to face the exam. These institutions are present as answers that the learning process in schools is considered still lacking and not maximal. However, the problems are: Why is learning in school considered not optimal? Is the material incomplete? Is the study time allocation still lacking? Is the learning strategy less effective? Is the learning atmosphere less conducive? If the problem is lack of material, then all the subjects given by courses are mostly covered in the school curriculum design. The curriculum given at each school is a systematic program. The curriculum has actually answered all of these questions. This is the fact that learning behavior of each student must be addressed according to the students' character, principles and life view of the community or learning community. So by doing this consideration, the school is truly a well-designed learning institution and has clear activities and goals.

Nowadays, the world of education is growing very rapidly. Standards for class upgrades, graduation, exams for 
new students in schools and university from time to time are higher. Unfortunately this is not balanced with the improvement of quality learning in existing schools and formal institutions. So, not a few students learn again after graduating from school, for example attending general courses or private courses. Some of the advantages of private courses compared to other learning patterns are (1) learning becomes more fun because the teacher positions himself as brother or friend (2) students are not reluctant to ask everything about learning difficulties they experience at school (3) intensive monitoring of students from both the teacher and parents (4) a flexible learning system in accordance with the students' needs (5) students will be more motivated to learn at home because there are teachers who are always ready to be consulted (6) learning speed can be adjusted with the level students'understanding so that all materials can be understood and (7) utilize free time at home to learn. These seven items can be seen from the learning psychology that the students' process and learning behavior is very complex. The complexity of student character and learning behavior must be addressed by educators. A teacher must be creative, not only placing his position as an instructor but he must also be able to portray himself as a brother, parent, or relative or other position that signifies the close relationship in learning so the students will feel comfort having family atmosphere.

Students who take additional learning programs in the form of private tutoring or courses have better academic progress when they are compared with students who do not attend the courses. On the other hand, many students who have encouraging achievements, even in many academic competitions, often win competitions, but students who do not join the courses may be due to various considerations including economic reasons, lack of motivation, lack of family support or other reasons. 
Starting from this background, several problem statements could be formulated for the research at MA NU Banat Kudus. They were (1) how isthe behavior of organization where the superior students learn? (2) how is the value system that underlies superior student attitudes and learning behavior? (3) how is the learning behavior of superior students in school? and (4) how is the learning interaction between teachers and superior students in school?

This research used a qualitative approach, pospositivistik paradigm. Research data were collected by interviews, observation and documentation. The data validity was tested using techniques, sources and time triangulation. Data were analyzed by Miles Hubermans interactive cycle technique. They are collecting, reducting, displaying and verifying. The subjects of this study were the MA NU Banat leaders, teaching staff, students and stakeholders. Research location was at MA NU Banat, Kudus, Central Java, Indonesia.

\section{B.Discussion}

\section{Culture of School Organization}

School as an organization has its own culture that is formed and influenced by values, perceptions, habits, educational policies, and the community behavior. As an organization, the school shows its peculiarities in accordance with the main objectives being carried out, namely learning. School culture should show capabilities that are in accordance with the demands of learning, namely to develop students in accordance with humanitarian principles. Therefore, it is precisely what is said by Deal, 1987; Brophy, 1987; Grossnickle, 1989; Lodkowski and Jaynes, 1990; that "an atmosphere or environment that nurtures the motivation to learn can be cultivated in the home, in the classroom, or at a broader level, through an entire school." 
School culture according to Phillips $(1993 ; 1)$ as the beliefs, attitudes and behaviors which characterizes a school. While Deal and Peterson (2004: 4) mean as deep patterns of values, beliefs, and traditions that have formed over the course of school's history. In this definition, the values of trust, attitude and behavior are the essential components of culture that shape the school character. School culture must be realized by all constituents as basic assumptions and beliefs that can make the school have a good image for stakeholders. Therefore all individuals have the same position to elevate image through performance that refers to an effective school culture. Effective school culture is the values, beliefs and actions as a result of a collective agreement which make commitment of all personnel to carry it out consistently and consistently. Mc Brien and R.S. Brandt (1977: 89) define school culture: definition of schoolculture: the sum of the values, cultures, safety practices, and organizational structures within a school that cause it to function and react in particular ways. Then, according to Stolp and Smith (1994: 232), school culture can be defined as the historical patterns of meaning that include the norms, values, beliefs, ceremonies, rituals, traditions, and myths understood, maybe in varying degrees, by members of the school community. This system of meaning often shapes what people think and how they act.

Based on those studies, the writer defines that school culture is as a typical characteristic of the school that can be identified through the adopted values, attitude they have, habits they display, and the actions shown by all school personnel that form a special unit of the school system.

\section{Learning Process}

The term 'learning' is the equivalent of the English word instruction, which means the process of making people learn. The goal is helping people to learn, or manipulate (engineer) the environment so it makes people who learn 
easier. Gagne and Briggs (1979) define learning as a series of events (events, events, conditions, etc.) that are intentionally designed to affect students (learners) so that the learning process can be done easily. Learning is not only limited to events carried out by the teacher, but includes all events that have a direct influence on the human learning process (Gagne; 1979). Learning is a process of interaction between students and their environment so that behavior changes occur well. In this interaction, there are many factors that influence it, both internal factors that come from individuals and external factors that come from the environment (Mulyasa, 2005: 255). Internal factors are dimension factors of students in accepting the changes. The external factors are the environment that can stimulate, support and facilitate the learning process. In learning, the main task of educators or teachers is creating the environment which can support the students' behaviour changes. From this definition, it can be stated that learning contains understanding which includes (1) Learning aims so that students can master the knowledge provided by the teacher, where students are only passive while the teacher is active. (2) Almost the same as the first, it is intended that students do not only know culture but also contribute in creating the nation or world culture in accordance with the demands of an ever-changing era (3) a teacher's effort to organize and manage the environment so that the situation and conditions can be nice for students to learn.

\section{Learning Theories}

\section{a. Behaviorism Theory}

If we examine the psychology literature, we will find many learning theories derived from psychology approach. Some learning theories are: (1) behaviorism theory; (2) cognitive learning theory according to Piaget; (3) 
information processing theory from Gagne, and (4) Gestalt learning theory.

Behaviorism is one of the psychology approaches that views individuals only in terms of physical phenomena, and ignores mental aspects. In other words, behaviorism does not recognize the intelligence, talents, interests and feelings of individuals in learning. Learning activity merely train reflexes in such a way that they become habits for individuals. Some learning laws are generated from this behaviorism approach, including:

\section{1) Connectionism (S-R Bond) Theory According to} Thorndike

Based on Thorndike's experiments on cats, the learning laws include: Law of Effect; it means that if a response produces a satisfying effect, the stimulus-response relationship will be stronger. On the contrary, the more unsatisfactory the effect achieved by the response, the weaker the relationship between stimulus-response will be. There are two principles in connectionism theory, namely (1) law of readiness; it means that readiness refers to the assumption that the satisfaction of an organism comes from the utilization of a unit of conduction unit, where these units cause a tendency that encourages the organism to do or not to do something (2) law of exercise; it means that the relationship between stimulus and response will be increasingly tight if it is often trained and it will decrease if it is rare or not trained (Haryanto, 2004: 63).

2) Classical Conditioning According to Ivan Pavlov

Based on Pavlov's experiments on a dog resulting the laws of learning, namely (1) law of respondent conditioning; the law of habituation that is prosecuted. If two kinds of stimulus are presented simultaneously (one of functions as a 
reinforcer), then the other reflexes and stimuli will increase (2) law of respondent Extinction, the law of extermination demanded. If the reflexes that have been strengthened through respondent conditioning are brought back without presenting reinforcer, then the strength will decrease (Jahja, 2003: 100).

\section{3) Operant Conditioning According to B.F. Skinner}

Based on experiments conducted by B.F. Skinner against mice and then to pigeons produces laws of learning, namely (1) law of operant conditining; if the emergence of behavior is accompanied by a reinforcing stimulus, then the strength of the behavior will increase. (2) law of operant extinction; if the emergence of operant behavior is strengthened through the conditioning process and it is not accompanied by a reinforcing stimulus, then the strength of the behavior will decrease and even disappear. Reber (Muhibin Syah, 2003) states that what meant by operants is a number of behaviors that have the same effect on the environment. The response in operant conditioning occurs without being preceded by a stimulus, but by the effect caused by the reinforcer. Reinforcer itself is basically a stimulus that increases the likelihood of a number of specific responses, but is not intentionally held as another stimulus pair as in classical conditioning.

\section{4) Social Learning According to Albert Bandura}

Social learning theory or also called observational learning theory is a learning theory that is relatively new if it is compared to other learning theories. In contrast to other Behaviorism adherents, Bandura views individual behavior not merely as an automatic reflex of stimulus (S-R Bond), but also due to reactions that arise as a result of interactions between the environment and the individual's cognitive scheme. The basic principle of learning according to this theory is that what individuals learn especially in social and 
moral learning occurs through imitation and presentation of behavioral examples (modeling). This theory still considers the importance of conditioning. Through reward and punishment, an individual will think and decide which social behavior that needs to be done. Actually there are many other figures who develop this behavioristic learning theory, such as: Watson with frequency and novelty principle, Guthrie with Contiguity Theory which produces the threshold method, the Fatigue Method and Unsuitable stimulation methods (The Incompatible Response Method), Miller and Dollard with the reduction of drive theory (Bandura, 1977: 35).

\section{b. Cognitive Learning Theory From Piaget}

Piaget was one of the figures called as a pioneer of constructivism. One contribution of his thoughts that is widely used as a reference for understanding individual cognitive development is the theory of the stages of individual development. According to Piaget, individual cognitive development includes four stages: (1) sensory motor; (2) pre operational; (3) concrete operational and (4) formal operational. Piaget's other views about the process of reconstruction of individual knowledge are assimilation and accommodation. James Atherton (2005) defined that assimilation is "the process by which a person takes material into their mind from the environment, which may mean changing the evidence of their senses to make it fit" and accommodation is "the difference is made to one's mind or concepts by the process of assimilation ". He also stated that learning would be more successful if it is adjusted to the cognitive development stages of students. Learners should be given the opportunity to experiment with physical objects which are supported by interaction with peers and assisted by questions of insight from the teacher. Teachers should provide a lot of stimulation to students to actively interact 
with the environment, find, and discover various things from the environment. The implications of Piaget's theory of cognitive development in learning are (1) children language and way of thinking are different from adults. Therefore the teacher teaches using language that is appropriate to the child's way of thinking (2) children will learn better when they can deal with the environment well. The teacher must help the child to be able to interact with the environment as well as possible (3) the material that must be learned by the child should be felt new but not familiar (4) provide opportunities for children to learn according to their developmental stages (5) in the classroom, children should be given opportunities to talk and discuss with their friends.

\section{c. Theory of Processing Information from Robert Gagne}

The assumption underlying this theory is that learning is a very important factor in development. The development is the cumulative result of learning. According to Gagne, learning takes place in the process of receiving information, and then processed to produce output in the form of learning outcomes. In information processing, there is an interaction between individual's internal and external conditions. Internal conditions are conditions of the individual that are needed to achieve learning outcomes and cognitive processes that occur in individuals. While external conditions are stimuli from the environment that affect individuals in the learning process. According to Gagne, the stages of learning process include eight phases, namely, (1) motivation; (2) understanding; (3) acquisition; (4) memorizing; (5) recall; (6) generalization; (7) treatment and (8) feedback.

\section{d. Learning Theory from Gestalt}

Gestalt comes from German language which has the equivalent meaning as "form or configuration". The point of 
the Gestalt view is that certain objects or events will be seen as something organized as a whole. According to Koffka and Kohler, there are seven most important organizational principles, namely (1) figure and ground relationship (2) proximity (3) similarity (4) common direction; (5) ) simplicity and (6) closure.

The applications of Gestalt theory in the learning process are (1) experience of insight; that insight plays an important role in behavior. In the learning process, students should have the ability to see, namely the ability to recognize the interrelations of the elements in an object or event (2) meaningful learning; the meaning of the related elements will support the formation of insight in the learning process. The clearer the meaning of the relationship of an element will be the more effective something learned. This is very important in problem solving activities, especially in identifying problems and developing alternative solutions. Something that students learn should have a clear and logical meaning to their life processes (3) pusposive behavior; behavior is directed towards goals. Behavior is not only the result of a stimulus-response relationship, but there is a connection with the objectives to be achieved. The learning process will run effectively if students recognize the goals that want to be achieved (4) the principle of life space; individual behavior is related to their environment (5) transfer in learning; namely the transfer of behavioral patterns in certain learning situations to other situations.

\section{Students' Learning Petterns}

Gagne (1977: 116) categorizes student learning patterns into several types in which one is a prerequisite for others who are higher in hierarchy. Those learning patterns are: 


\section{a. Signal Learning}

This type of learning occupies the hierarchy stage (the most basic). Signal learning can be defined as the process of mastering the basic pattern of behavior that is involuntary (unintentional and based on its purpose). The conditions needed for this type of learning are giving simultaneous stimuli.

\section{b. Stimulus-Respons Learning}

This type of learning is included in the operant or instrumental condition (Kible, 1961) or learning by trial and error (Thorndike, 1977). The conditions needed for this learning type are reinforcement factors

\section{c. Chaining and Verbal Association}

Both these types of learning are equivalent, learning to connect the S-R bond units to one another. This type of chaining is related to aspects of psychomotor behavior and type of verbal association regarding aspects of verbal learning. The conditions needed for the ongoing learning process is that the students must have mastered a number of S-R pattern units, both psychomotor and verbal. In addition, the principle of contiguity, repetition, and reinforcement still play an important role for the ongoing process of chaining and association.

\section{d. Discrimination Learning}

In this learning phase, students hold discrimination (selecting and testing) between two stimulants or a number of stimuli they receive then choose the welcome patterns that they consider most appropriate. The main condition for this learning process is that students have the skills to do chaining and association and have a wealth of experience (S-R unit patterns) 


\section{e. Concept Learning}

Based on the characteristic similarities of a set of stimuli and also their objects, they form an understanding or concepts. The main conditions needed for this type of learning process is the mastery of discrimination skills and previous fundamental cognitive processes

\section{f. Rule Learning}

At this level, students learn to make combinations of various concepts (understanding) by operating formal logic rules so that students can make certain conclusion.

\section{g. Problem Solving}

At this level, students learn to formulate and solve problems (respond to stimuli that describe or arouse problematic situations) by using various rules that have been mastered.

Nowadays, learning theorists have tried to portray the approach or system of teaching or the teaching-learning process. Some of the various current teaching systems are:

\section{b. Enquiry-Discovery Learning}

In this teaching and learning system, the teacher presents learning material that is not in its final form. Students are given the opportunity to find by themselves using problem solving approach techniques. Generally, the procedure is the stimulation of problems-data collectiondata analysis-verification-generalization. This teaching and learning system was developed by Bruner (Lefrancois, 1993: 124). This learning approach is very suitable for cognitive subject matter. Its weaknesses, among others, take a lot of time and if it is not guided and directed, it can lead to obscurity on the material learnt. 


\section{i. Expository Learning}

In this system, the teacher presents the material that has been prepared in a good, systematic and complete step so that the students listen and understand it regularly and orderly. Generally, the procedure is the approach-evaluationpresentation-evaluation. Ausubel argues that at higher learning levels, students do not always have to experience it themselves. Students will be able and more efficiently obtain as much information as possible in the shortest possible time. The important thing is the students develop their mastery over the framework of basic concepts or patterns of basic understanding so they can organize data, information, and experiences related to it.

\section{j. Mastery Learning}

This learning process that is oriented to the principle of mastery learning must begin with mastery of the smallest part and then be able to proceed to the next unit or module. Based on that basis, today a program of teaching systems has been developed as well as a system of teaching modules, even internet-based learning. With the achievement of a high level of learning outcomes mastery, it will show the students' healthy mental attitude.

\section{k. Humanistic Education}

This learning theory focuses on helping students so that they are able to achieve self-realization in accordance with their basic abilities and uniqueness. The main characteristics of this method, among others, are that the teacher should not make a distance with students. The ultimate goal of the teaching and learning process according to this understanding is that self actualization is as optimal as possible for each student. 


\section{Madrasa Culture and Students' Character Formation}

MA NU Banat is an Islamic Senior High School with the ideology of ablussunah waljamah, a religious understanding in Islam that is guided by the way of salvation following the sunnah of prophet Muhammad and his followers. All students in this madrasa are female students. MA NU Banat has become a national reference for the Indonesian Muslim community to entrust their sons and daughters to be pious children. In addition, MA NU Banat with the spirit of progress and acceleration succeeded in obtaining ISO 9000 certificates.

This madrasa culture is formed by the culture of kyai, santri and pesantren as well as the determination to realize noble human beings, who are superior or excellent in the academic field, have a noble attitude that is based on ablisunnah waljama'ah. All learning programs in madrasa aim to realize the madrasa vision. The madrasa vision is made on the basis of this madrasa culture and history.

Komariah (2005: 4) explains that the vision and culture of the organization are closely related. Vision is made on the values and main views of an organization. Core beliefs are basic beliefs of the organization and core values are as the core values that shape organizational culture.

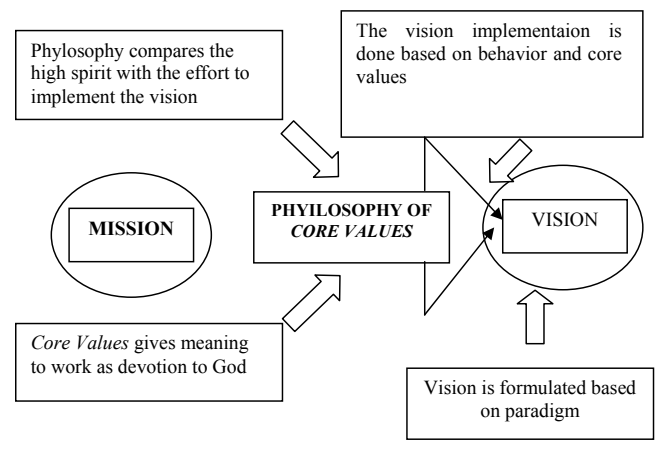

Figure 1

Correlations among Vision, Mission, Core Beliefs, dan Core Values 
That figure can be understood that the values and beliefs of an organization made as a philosophy to realize the vision. It affirms that vision is the final manifestation of the embodiment of organizational culture. The character of the superior students who want to be dreamed in this madrasa cannot be separated from the character and culture of the organization. Madrasa culture is maintained, preserved and developed by madrasa leadership in accordance with the dynamics of science and knowledge. Madrasa leaders have positions and responsibilities to maintain a strong, dynamic and characterized madrasa culture.

The meeting or "kumpulan" tradition is preserved as a function of coordination meetings. Time and title of "kumpulan" activity that is outside of working day has bocome tradition and an adhesive medium for people at Madrasa to realize superior and good students. The following is an example of "kumpulan" activities arranged for coordination function.

Table 1

Kumpulan Tradition for Coordination Function

\begin{tabular}{|c|l|l|}
\hline No & \multicolumn{1}{|c|}{ Name of Kumpulan } & \multicolumn{1}{|c|}{ Activities } \\
\hline 1 & $\begin{array}{l}\text { Kemisan, every Thursday } \\
\text { night }\end{array}$ & $\begin{array}{l}\text { Learning the holy book of Tasawnf } \\
\text { Bidayatul Hidayah and nashoo'ihul I'baad }\end{array}$ \\
\hline 2 & $\begin{array}{l}\text { Ahadan, every Sunday, } \\
\text { in the beginning of each } \\
\text { month }\end{array}$ & $\begin{array}{l}\text { Istighosah and pengajian (learning everything } \\
\text { about Islam) }\end{array}$ \\
\hline 3 & $\begin{array}{l}\text { Loronan, every (date) ind } \\
\text { of each month }\end{array}$ & $\begin{array}{l}\text { Coordination about language (Arabic and } \\
\text { English) }\end{array}$ \\
\hline 4 & $\begin{array}{l}\text { Neman } \\
\text { Coordination of the classroom captains } \\
\text { and the counseling coordinator }\end{array}$ \\
\hline 5 & Songonan & Coordination about internet management \\
\hline 6 & Sewelasan & Coordination about superior class \\
\hline 7 & Rolasan & Koordinasi about literature \\
\hline 8 & Telulasan & $\begin{array}{l}\text { Coordination about ponpes Yanabi'ul ulum } \\
\text { warrahmah management }\end{array}$ \\
\hline
\end{tabular}




\begin{tabular}{|c|l|l|}
\hline 9 & Pitulasan & $\begin{array}{l}\text { Coordination about cooperatives and } \\
\text { bussiness entities }\end{array}$ \\
\hline 10 & Rungpuluhan & $\begin{array}{l}\text { Coordination of classroom captain and the } \\
\text { vice chairman of students' affairs }\end{array}$ \\
\hline 11 & Selikuran & $\begin{array}{l}\text { Coordination about MGMP or subject } \\
\text { teachers }\end{array}$ \\
\hline 12 & Padelikuran & $\begin{array}{l}\text { Coordination between homeroom teacher } \\
\text { with picket teacher }\end{array}$ \\
\hline 13 & Songolikuran & Coordination about the cleanness \\
\hline
\end{tabular}

Source: Primary Data, 2018.

Kumpulan loronan, eneman, sewelasan and so on as the name of kumpulan/meeting taken from the date when the gathering or meeting is held. These activities have coordination objectives through the organizational culture traditions that have been preserved.

Taking priority to spiritual capital and social capital towards financial capital and human capital are the main values of madrasa to build the character of madrasas in real life and hereafter, oriented towards the attainment of the perfection of life based on illahiyah's goals and motivations. Educational institution is non-profit organization category characterized by social mission orientation. Good social and spiritual life is a big capital that is not valuable if it is moved and managed properly. The spiritual and social capital is not directly related to MA NU Banat, but the efforts of MA NU Banat by empowering the potential friendship, harmonious and empowered social management will have implications for material benefits and finally, it will elevate human dignity and status. Sri Roikhanah (2017) said that:

"...saya melihat MA NU Banat ini sebagai lembaga yang guru-gurunya tidak digaji dengan jumlah yang tinggi, sebagian besar dari kami adalah guru-guru swasta, tetapi kami yakin bahwa lembaga ini sangat kaya dengan sistim nilai yang dibangunnya sehingga menyebabkan lembaga ini menjadi besar. Banyak orang ikhlas mengabdikan diri di lembaga ini dan saya melihat teman-teman bekerja penuh 
dengan kesungguhan dan kerja keras demi mencapai tujuan utama madrasah, saya juga melihat di lembaga ini orangorang satu sama lain sangat akrab, bersemangat, bahu membahu, saya juga melihat setiap pagi, siang hari siswa beristighosah (berdo'a bersama dengan bacaan-bacaan khusus), saya melihat banyak anak-anak yang berprestasi, jarang saya melihat pertengkaran, jarang saya mendengar dan melihat ada kemaksiatan...."

"... I see MA NU Banat as an institution which has teachers with little salary. Most of us are private teachers, but we are sure that this institution is very rich in the value system so it makes this institution become bigger. Many sincere people devote themselves to this institution and I see friends working full of sincerity and hard work to achieve the main goals of the madrasa. I also see in this institution, the people are very friendly, passionate and hard worker. I also see the students pray together every morning. I see a lot of children who have achievements, I seldom see the quarrels, I rarely hear and see disobedience ...."

\section{Basic Principle and Value of MA NU Banat Organisation}

Madrasas or other educational institutions are rare to make written documents from a value system as the basis for the educational administration. MA NU Banat has made efforts to prove as an advanced madrasa by creating and disseminating a value system that becomes spirit and make that spirit as a 'driving force' for all parties related to education programs at MA NU Banat, especially for the leaders, teachers, staffs and all students.

There are 27 value systems developed in MA. NU Banat. They are (1) Message of Shaykh KH Sya'roni Affandi which includes (a) carrying out all activities with worship (b) having good behavior (harmonious and cooperative) (c) do not deliberately make mistakes or break the rules. If someone do it, he must repent immediately (2) 3D (Three Disciplines), 
which includes (a) time discipline (b) the discipline of worship and (c) the discipline of learning (3) carrying out activities with the guidance of the heart and giving good deeds "helpful, right, not forced and patient, conscientious and careful with the understanding (a) be cool so that the heart feels calm (b) can patiently be with God: (ان الله مح الصيابرين) (c) be careful, not to be wrong (d) be careful to be safe (4) practice what the prophet did. They are "ngapes, ngalah, ngasor, ngegungke liyan" with interpretation (a) ngapes, feel himself weak; the strong one is only Allah (b) ngalah, apply to succumb; the winner is only Allah (c) ngasor, apply inferiority; the great one is only Allah (d) ngegungke liyan, glorify other parties on the basis of tawadlu' and politeness; (5) always doing everything with the foundation and the principle:

$$
\text { لا يستقيم الحال بالاهمال ولا يصلح الامر بالاغفال }
$$

(6) job description is arranged based on the principle of mutual help (7) madrassa practices the fatwa or instructions from the kiai because based on the history, the madrasa founding involves a large role of kyai who thought of the dignity of Muslim women (8) prioritizing social capital towards financial capital and human capital (9) building financial capital through empowering student guardians who have given credence to MA NU Banat (10) managing and enhancing social capital with 3 objectives (a) empowering all madrasa citizens (b) empowering society trust to MA NU Banat and (c) empowering relationships with related institutional structures (11) increasing social familiarity, eliminating manipulation with routine evaluation, monthly, weekly and incidental meetings (12) developing social glue with istighosah manaqiban every malam Jumat or Thursday night and istighosah every day at the beginning of the month and also (13) preserving forums that are very useful for improving education (14) coordinating with Islamic boarding schools 
(15) coordinating with students' guardians, especially jointly guarding students from wearing jewelry, not carrying cellphones, not dating, not taking goods owned by others and prohibition of being absent more than three times (16) developing a good network with relevant agencies (17) inviting relevant officials during meetings with student guardians (18) debriefing students who graduated through collaborating with Islamic boarding schools tahfidh Yanbu'ul Qur'an in various activities, especially concerning what should be done by the alumni after completing their studies. (19) In order to plant student discipline, students who are late may not take lessons for an hour and must do the assignments given by the picket teacher (20) imposing 10 managements which include curriculum, human resource, students, facilities, PBM, financial, results, context of physical and non-physical environment, impact and system management (MPMBM) (21) madrasa spirit is the practice of Islam as the basis of social capital (22) sincerity is the basis of all dedication charities (23) taking part in condolences towards the citizens of madrassas who passed away (24) all twelfth graders are required to carry out istighosah which includes; khotmil qur'an at least 3 times, fatihah 70 times with prayer, Manaqib Shaykh Abdul Qadir Al Jailany and Asmaul busna (25) the goal in MA $\mathrm{NU}$ Banat is not to get world rewards but to get rewards for the afterlife, get barokah (26) uniting social capital and spiritual capital are continuously developed with the spirit of religion which is carried out step by step (27) greeting the families of MA NU Banat with the intention of implementing the message of Rasulullah so that there will be more and more affection between the family of MA NU Banat. The Prophet Muhammad said:

$$
\text { اول ادلكم على شيئ اذا فعلتموه تحابيتم افشو ا السلام }
$$


«I will give you the guidance, if you observe, you will love each other. Give greetings among you «.

\section{Learning and Achievement}

The learning behavior or attitude of students is actually very complex. Behavior or learning attitude depends on internal and external factors of students. Internal factors involve the habits, character, personality, and the orientation of each student in learning. Students who have good academic achievement are students who tend to have more solid time and learning activities. The behavior or learning attitude of students is actually very complex.

The achievements obtained by students are the result of hard learning process and perseverance, discipline and prayer. According to a student, studying at home is not just when there is homework from the teacher, but they have to study every time. For students, a good achievement is the collaboration of all related elements; students must be diligent in studying, parents and teachers must accompany and follow students' progress carefully. When student has a problem, the teachers and his parents must immediately find out and find a solution. Teachers and students must be proactive to students especially if they meet closed students. Good achievement is supported by conducive learning facilities and systems. According to their experience, the students who stay in dormitory will be more maximal in learning when they are compared to students who live at home. It means that learning with good condition will also make good results.

\section{Superior Students Supported by the Quality of Headmaster's Leadership}

Memimpin suatu lembaga adalah merubah lembaga dari yang belum baik menjadi baik, merubah dari yang belum 
sama dengan yang lain menjadi sama dengan yang lain bahkan lebih baik. Filosofi itu juga menjadi dasar bagi kepemimpinan kepala MA NU Banat. MA NU Banat sebagai pusat uggulan pendidikan putri ini telah meraih berbagai prestasi dan telah mendapatkan kepercayaan yang luas dari masyarakat. Ini karena semangat ingin maju di bawah kepemimpinan kepala madrasah. Tanpa semangat, kerja keras dan kerjasama dari pihak yang terkait, maka mustahil MA NU Banat mampu meraih ISO 9001 dan ISO 2000. ISO 2008. Sertifikat ISO yang telah diperoleh oleh MA NU Banat adalah sebagai bentuk pertanggungjawaban MA NU Banat kepada masyarakat yang telah memberi kepercayaan. Di samping ISO tersebut MA NU Banat telah banyak mengantarkan peserta didiknya yang telah lulus untuk meneruskan pendidikan yang lebih tinggi sesuai dengan potensi, minat dan bakat yang dimilikinya. MA NU Banat juga telah mengantarkan peserta didiknya untuk kembali menjadi masyarakat yang berguna bagi keluarga maupun bagi masyarakat serta mampu menjadi pribadi yang salihah.

Leading an institution is changing institution that is not good to be good and changing from those that are not the same as others to be equal to others even better. The philosophy is also the basis for the leadership of the head of the MA NU Banat. MA NU Banat as the center for female education has won various achievements and has gained wide trust from the community. This is caused by the spirit to be progressive under the leadership of headmaster. Without enthusiasm, hard work and cooperation from related parties, it is impossible for MA NU Banat to be able to achieve ISO 9001, ISO 2000 and ISO 2008. The ISO certificate that has been obtained by MA NU Banat is a form of accountability of MA NU Banat to the people who have trusted. In addition, MA NU Banat has led many students who have 
graduated to continue their higher education in accordance with their potential, interests and talents. MA NU Banat has also led students to become good people who are useful for families and community.

\section{Conclusion}

Students who have good academic and non-academic achievements such as arts and sports are students who join school organizational units that are committed to the progress spirit. Organizational culture that prioritizes academic quality, oriented towards strengthening positive character and being nurtured continuously in the school system by all members of the organization strongly supports the realization of superior, competitive and characterized student achievement. In contrast, if the schools have a low organizational culture and lack of commitment to school institutions, the students are less to get achievements. If the student gets an achievement, it is caused by the talented student.

The source of values or view of life that makes students become superior achievers are the main principles about the values from the formation of the family environment, the people's view of life and the view of life built by the school where students study: obedient and consistent attitude towards religious teachings, discipline, being on time, studying hard, competing to get the best achievement, honesty, and independence. If the virtue of these values used in the implementation of education and teaching and learning activities, the best performance of students will be very easy to obtain

Students who get a tight schedule of learning activities are more likely to get good achievements. Those who stay in dormitories have the opportunity to have more time and learning activities. If students do not stay in a dormitory, 
they get an intensive learning program with additional time until the afternoon and or take additional private lessons / courses.

The typology of behavior and learning attitudes of high school students is very dependent on school learning programs. Factors driving external student learning are more dominant than internal learning awareness. The more rules and structured tasks made by schools and subject teachers, the students' attitudes and learning motivation will be more intense and vice versa. This is caused by the awareness of the concept and orientation of life going forward for high school-level students is still unclear, so internal motivation that drives learning for the sake of an ideal and achievement is not strong enough.

Students will be encouraged to learn more optimally if they are accompanied by a teacher who has a close relationship with them. Superior students have a tendency to have close relationships with teachers. Teachers for superior students are as their parents, as teachers who must be able to put themselves as a place to ask, can be invited to communicate closely and open in various problems, and help students to solve problems whether it is academic or non-academic problems so that good achievement can be achieved by the students. 


\section{REFERENCES}

Ali, Mohamad. Guru dalam Proses Belajar Mengajar. Bandung: Sinar Baru, 1984.

Bandura, Albert. Social Learning Theory. New Jersey: PrenticeHall, Inc., 1977.

Bogdan, R.C. and S.K. Biklen. Riset Kualitatif untuk Pendidikan: Pengantar Teori dan Metode, transl. Munandir. Jakarta PAU, Dirjen Dikti Departemen Pendidikan Nasional, 1982.

Bush, Tony and Marianne Coleman. Manajemen Strategis Kepemimpinan Pendidikan, trans. Fahrurrozi. Yogyakarta: IRCiSoD, 2006.

_. Leadership and Strategic Management in Education. London: Paul Chapman Publishing Ltd., 2000.

Departemen Agama RI. Kurikulum Madrasah Aliyah Tahun 1994: Landasan Program dan Pengembangan. Jakarta: Dirjen Binbaga Islam, 1998.

_. Profil Madrasah Aliyah Keagamaan. Jakarta: Dirjen Binbaga Islam, 1998/1999.

Fajar, Malik. Madrasah dan Tantangan Modernitas. Bandung: Mizan, 1998.

Gagne, R.M. The Condition of Learning and Theory of Intruction. New York: Holt Renehart and Winson, 1977.

Haryanto, Budi. Psikologi Pendidikan dan Pengenalan Teori-teori Belajar. Sidoarjo: Universitas Muhammadiyah Sidoarjo, 2004.

Jahja, Yudrik. Psikologi Perkembangan. Jakarta: Kencana Prenamadia Group, 2013. 
Kimble, Gregory Adams, dkk. Conditioning and Learning. London: Century Psichology Series, 1961.

Komariah, A. and T. Cepi. Visionary Leadership: Menuju Sekolah Efektif. Jakarta: Bumi Aksara, 2005.

Lefrancois, G.R. The Life Span. Calfornia: Wadsworth, Inc., 1993.

Mulyasa. Manajemen Berbasis Madrasah: Konsep, Strategi, dan Implementasi. Bandung: Remaja Rosdakarya, 2002.

Sardiman. Interaksi dan Motivasi Belajar Mengajar. Jakarta: Raja Grafindo Persada, 1986.

Steenbrink, Karel A. Pesantren, Madrasah, Sekolah: Pendidikan Islam dalam Kurun Modern. Jakarta: LP3ES, 1974.

Waajosumidjo. Kepemimpinan Kepala Sekolah: Tinjanan Teoretik. dan Permasalahannya. Jakarta: Rajawali, 2003. 
Nadhirin

Halaman Ini Tidak Sengaja Untuk Dikosongkan. 